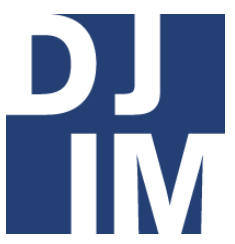

Volume 13

Spring

2017

djim.management.dal.ca |

\title{
Be mindful of the future: information and knowledge management in Star Wars tie-in fiction
}

Diana Castillo

School of Information Management, Dalhousie University

\begin{abstract}
In the last fifty years, media franchises have been using tie-in fiction to expand their universes and tell stories outside the main source material. This paper examines how information management is used specifically in Star Wars tie-in fiction and its recent transition to using knowledge management. To start, this paper looks at the history of tie-in fiction from its roots in the 1960s to the modern day, before transitioning to the role of brand managers and editors as information managers. Then, this paper documents the history of Star Wars tie-in fiction and how information management strategies were implemented through 2014 and how it impacted the franchise's internal continuity. Finally, this paper examines the recent move towards a unified canon and how this shift towards knowledge management has impacted storytelling. This paper concludes that while it is too early to evaluate its results, Star Wars was uniquely situated among franchises to move towards knowledge management through its prior information management efforts.
\end{abstract}

\section{Introduction}

In today's entertainment environment, popular franchises are rarely limited to one type of media. They license their products across various different formats to engage fans and expand their footprint in popular culture as much as possible. One of the most common forms used is the tie-in novel. Many visual media franchises, from the video game Mass Effect to the television show Leverage, use prose fiction to grow their respective universes and tell stories they may not be able to tell otherwise. Creating a well-run line of tie-in fiction requires coordination between authors, publishing houses, and the licensing company through information management. In the context of this paper, information management is defined as working with various stakeholders (writers, license owners, editors, etc.) in order to ensure the details of a shared universe are consistent. One franchise that has been particularly successful in leveraging its brand through tie- 
in fiction is Lucasfilm for Star Wars. Starting shortly after the release of the original film through the present day, Star Wars tie-in books have become a key part of its brand. For a long time, however, Lucasfilm maintained different levels of canon (events that are considered absolutely definitive in a shared universe) across its various licensed products, including its novel line. This created a situation where even with systems in place to manage information and knowledge about the series, continuity errors and different interpretations of the source material occurred (Hidalgo, 2012). Only recently did Lucasfilm fully align its canon across all tie-in mediums, including books, with the help of a centralized Story Group, a group of producers and creative executives charged with steering the company's overarching narrative. Lucasfilm's move to a unified canon allowed for better integration and information transfer among the different components of the company to the publishing arm and allowed them to make a shift to using knowledge management within the company in order to facilitate long-term planning, growth, and execution of strategy.

\section{Tie-In Novels, Franchises, and Canon}

Franchise writing began to take shape with the advent of television. In her overview of the history of tie-in fiction, Charlie Jane Anders (2009) noted that, while today Doctor Who and Star Trek are known for their novels, they were not the pioneers in the field when they began in the 1960s. Instead, other television shows like The Avengers, The Man from U.N.C.L.E., and The Six-Million Dollar Man began publishing books that continued the adventures of its characters beyond the small screen (Anders, 2009). It wasn't until Star Trek left the air in the 1970s and 1980s that its tie-in novels began to explode in number and in popularity, with authors like
Diane Duane and Barbara Hambly contributing to the universe. The number of tie-in fiction works continued to grow in the 1990s, with the advent of the Doctor Who line and the Star Wars Expanded Universe (EU). When surveying the state of tie-in fiction at the time, Anders (2009) writes that at this point, nearly every decently-sized TV show from Buffy the Vampire Slayer to Alias began investing in a line of tie-in novels. Today, while few TV shows have an associated print universe, video games have been filling that space. Games such as Halo, Mass Effect, and Dragon Age have published multiple tiein novels focusing on events outside of gameplay.

One important element of tie-in novels is that they allow for the exploration of events outside of an episode, movie, or game. Diane Duane, for example, wrote a series of wellreceived novels focusing on the Romulan culture and society, despite the species only appearing in one episode of the original series with little explanation other than they were an offshoot of the Vulcans (Anders, 2009). For shows like Star Trek or Doctor Who, which were no longer airing at the time their tie-in novels exploded in popularity, the print adventures of their favourite characters were the only new content the fans were receiving. Even when the shows returned to the air, the popularity of their tie-in novels continued, but now they only focused on stories that could feasibly take place between episodes. The companies' respective licensing departments oversaw the publishing line to ensure the novels aligned with the source material, but authors also had the freedom to explore or create new characters. Tie-in novels give franchises the flexibility to broaden their universes and present new concepts and characters for fans to enjoy, albeit with some caveats. 
For most franchises, tie-in novels are a way to grow the brand and to keep their fans engaged in the stories being told; however, they are not considered to be the same level of canon that episodes or movies are. For most franchises that began as TV shows or movies, canon is what is shown on the screen. Novels and comics, while part of the universe, are not considered to be canon and thus can be overwritten by the source material later on, and are rarely included in the future development of the main franchise. For example, while Diane Duane's Romulan novels were held in high esteem by fans, they were contradicted by later on-screen appearances of Romulan society, most notably with the film Star Trek Nemesis. When asked by the website io 9 about her reaction to the film contradicting her novels, Duane replied:

I've been working in both TV/film for long enough that I knew perfectly well where books fit into the mass-media pecking order (quite low down...), and what was likely to happen to noncanonical material when it came into contact with a production crew eager to prove that it wasn't beholden to anybody else's take on the Romulans. (Anders, 2008, para. 3)

Despite working closely with the respective brand's licensing division, authors are aware that at any point in time their work can be contradicted by the source material. The licensing representatives can help mitigate that harm by giving input into story ideas or vetoing pitches that could impact the future of the franchise (such as killing Captain Kirk in a novel), but that is the extent of it. Brand managers ensure that authors are aware of the current state of the shared universe and help answer questions about the finer details. It does not mean that they work with show or movie producers to translate the novel's events to the visual medium. The flow of information, in this case what material is considered canon, for tie-in fiction only goes one way, from the source to the licensed products. Franchise writing is tied to the source material, but rarely impacts it.

\section{B rand Managers, Information, and Collaboration}

Because there are numerous creators working in a shared universe at any given time, there runs the risk of accidental duplication and internal inconsistency. For tie-in fiction, authors work with editors and members of the company's licensing department to formulate their story and mitigate those harms through good information management practices. In J ohn Jackson Miller's (n.d.) blog post detailing the behind the scenes activity for his Star Trek novel, Takedown, he points out that suggestions from both his editor and the executive at CBS licensing resulted in changes to his initial story idea, which made for a stronger novel. His editor, who worked on the larger Star Trek line, was familiar with stories already being told through other novels and was able to give input on what characters could be used for maximum storytelling impact (Miller, n.d.). The editor also, according to Miller (n.d.), pointed out that the conflict at the emotional core of the novel already occurred, and switching roles of the characters could lead to a richer, more interesting story. Miller, a full-time author who had just finished writing a tie-in novel for Lucasfilm, did not have the familiarity with the novel line and the character beats that the editor did.

Brand managers, in this case individuals operating within a company's licensing division, serve as information managers for a 
shared universe. This can include keeping a detailed timeline of events; maintaining a database of characters, settings, and vehicles; or working to ensure storylines are not accidentally duplicated. Editors within a publishing house specializing in the licensed product can serve as information managers in this situation as well. Tying into the definition of information management, their responsibility is to ensure that authors have the information they need to write in a shared universe. For a franchise with a large quantity of information in the form of episodes, novels, or comics, having someone who can work with authors and provide feedback about the current state of the universe is essential. W ithout this brand management, the shared universe inhabited by the novels would become difficult to navigate for fans and possibly lead to frustration with the franchise as a whole.

Although many tie-in lines practice information management in this format, knowledge management is a different story. For this paper, knowledge management means collaboration across different departments in a company to plot the future of the franchise, ensure consistent storytelling across mediums, and work with creators to implement a larger vision for the brand. While there may be knowledge management being implemented in the source material-for example, Kevin Feige ensuring that all the Marvel movies are interconnected and planting seeds for future films in the current ones-this rarely extends to tie-in materials.

\section{Star Wars Tie-In Novels - From Standard to Unique}

Until 2014, Star Wars' relationship with its licensed materials followed the same pattern as other franchises, albeit with a few key changes. The licensed tie-in materials were collectively referred to as the expanded universe $(E U)$. Although the EU contained multiple characters beloved by fans, those characters or stories were rarely acknowledged by the movies or TV shows. In his introduction to Star Wars: The Essential Reader's Companion, Pablo Hidalgo (2012) notes that for Star Wars, the most definitive canon came directly from George Lucas, and it was his vision that dictated the source material. The EU, while related to the story created and overseen by Lucas and managed by his company, was a separate entity (Hidalgo, 2012). At a panel during Star Wars Celebration in 2015, Hidalgo elaborated further, stating:

In the past there were two camps kinda developing the story. The intent was to have them interact as much as possible, but the reality was that the cinematic entertainment [...] and the published entertainment weren't as in sync as they could be. (Larsen, 2015)

One thing that made Star Wars fairly unique among franchises was that it codified the different levels of canon through nicknames. The movies, and eventually the TV series Star Wars: The Clone Wars, were known as "G-level" canon after creator George Lucas, while the books, comics, and other licensed material were referred to as continuity level or "C-level" (Chee, 2006). Certain aspects of "C-level" canon might appear in "G-level," such as the name Coruscant for the galactic capital world or the occasional character appearing on screen; however, G-level canon can and did overwrite established elements of $\mathrm{C}$-level if events in the movies or TV show contradicted events or characterizations in previously published novels (Zahn, 2011). 
The contradictions between different mediums began with the very first EU novel, Splinter of the mind's eye, published in 1978. Written by Allan Dean Foster, the book was set after the events of A New Hope. In his annotation for the novel in the Essential Reader's Guide, Hidalgo (2012) writes that despite being based on an unused treatment for a second film, the book's events and characterizations were contradicted by the release of Empire Strikes Back and Return of the Jedi. He also notes that his book contradicted events in the Marvel Comics series due to the lack of a centralized information management system between the two license-holders (Hidalgo, 2012). This lack of consistency in licensed materials appears to stem from Lucasfilm making no effort to align continuity across different mediums, as well as not communicating plans for future movies with the author. Despite being the earliest entry into the EU, the novel became ignored and its impact on the larger universe was negligible. The lack of internal consistency continued to be a feature of Star Wars tie-in fiction, despite information from Brian Daley's Han Solo trilogy being incorporated by the tabletop gaming company, West End Games, into their Star Wars sourcebooks (Hidalgo, 2012). The licensing focus was on merchandise, not the published tie-in materials. Attempting to align the novels and comics, as well as to create some form of information management system would not occur until later.

The change that shifted the course of the Star Wars EU began at the end of the 1980s and impacted the next few decades of storytelling for Star Wars licensed products. In 1989, six years after Return of the J edi and ten years before the first prequel movie, Lucasfilm began exploring the possibility of publishing an adult line of novels (Zahn, 2011). Lucasfilm approached the publisher Bantam Books, who then reached out to rising science fiction novelist, Timothy Zahn, about the possibility of writing a new trilogy of tie-in novels. The only caveat from George Lucas, according to the head of licensing, Howard Roffman, was that the novels had to be set after the events of the original trilogy, since he was interested in creating prequel films (Zahn, 2011). With this in mind, Zahn worked with Lucasfilm to put together an outline for a story taking place five years after the events of Return of the J edi (Zahn, 2011). It was hoped that the new series would not only revitalize interest in a "dead" franchise, but also prove to be a viable publishing path moving forward.

While there were few other licensed novels to work around at the time, West End Games was publishing supplementary materials and guidebooks for their roleplaying game. For the first time, these guidebooks named countless characters, vehicles, and alien species found in the movies in order to categorize a universe (Veekhoven, 2015). In an attempt to start creating a cohesive universe for fans to enjoy, Lucasfilm mailed Zahn copies of what West End Games had produced up until that point and asked Zahn to use them as a resource when writing his novels (Zahn, 2011). The plan appeared to be, if Zahn's novels were successful, to use those sourcebooks as an essential resource for authors writing in this shared universe. The lack of an internal database left these guidebooks as one of the few official sources of information that was readily accessible for both fans and writers.

While there was an attempt to align the information in Zahn's books with the West End Games materials, the same could not be said with the other large project undertaken 
by Lucasfilm at the time. When Zahn was approached by Lucasfilm and Bantam Books about the possibility of writing the novels, a comic series set in the same time period was already under development. Although this paper is looking specifically at the Star Wars prose line, this brief detour into the comics' line is necessary to underscore the lack of centralized information management and how it affected storytelling in future Star W ars licensed products.

In development for about one year before Lucasfilm began exploring the possibility of an adult novel line, Star Wars: Dark Empire began as a pitch from author Tom Veitch to create a comic book miniseries exploring what might happen if Luke Skywalker fell to the Dark Side of the Force (Kogge, 2015a). After receiving approval from Lucasfilm in 1988, a series of delays pushed it back until it was then scheduled to be published after Zahn's first novel, Heir to the Empire. Because the two projects were going to be set during the same time frame after Return of the Jedi, this presented a major complication for both writers. As noted previously, in the past there was no internal continuity between the early novels and the comics published by Marvel Comics, and there did not appear to be anyone in the licensing department assigned to oversee how the two projects might interact. Unless Lucasfilm wanted to confuse or alienate fans by creating conflicting continuities between the two mediums, communication was needed between the two parties to ensure some cohesion despite their very different visions about what Star Wars was and what it could be (Kogge, 2015b).

In the end, Veitch solved the problem by having Dark Empire take place after the conclusion of Zahn's trilogy and acknowledging the events that occurred in his script (Kogge, 2015b). In his retrospective on Dark Empire, Michael Kogge notes that this compromise led to the creation of the EU timeline used by both comics and novels to create a continuity for licensed products to utilize a moving storyline (Kogge, 2015b). This timeline formed the basis of the $E U$, with the unofficial creation of "C-level" canon through the coordination between Veitch and Zahn. But, while licensing worked with authors on stories and what could be included, there was still a lack of coordination that affected continuity further down the line.

Zahn's trilogy-later designated as the Thrawn Trilogy after its main villain-proved to be immensely successful, and launched the new Star W ars publishing line. In the time that Bantam Books held the license from 1991 to 1999, they published thirty-seven novels and several short story collections. While the editors and the licensing department did their best to ensure that the timeline established by Zahn and Veitch was used, events and characterization did not always align. It could be interpreted that character traits did not always align because many books were developed in a short amount of time, and communication between different parties did not always occur. For example, in the annotation for the novel New R ebellion, Hidalgo (2012) notes that a similar event occurred in a previous novel, but with the character involved responding in very different ways. Hidalgo (2012) posits that if a reader is looking for an in-universe explanation, one could be found, but the duplication actually occurred due to the books being developed at the same time. This lack of communication and sharing of information about characterization between different projects undercut efforts to create a more cohesive and unified shared universe. Much like the situation with Zahn and Veitch, 
each author had their own vision about what Star W ars entailed and there was little effort in ensuring a consistent tone or characterization across the novel line.

The turn of the century saw several changes in the publishing program and Lucasfilm in general. After nearly a decade of working with Bantam Books, Lucasfilm switched publishers to Del Rey. This meant new editors, new directions for stories, and a chance to restructure the novel line. Under Bantam, books were written and conceived in relative isolation from each other. The thirty-seven novels they published, with an exception for the $\mathrm{X}$-Wing series, were either single books or standalone trilogies (Hidalgo, 2012). Del Rey, armed with the growing shared universe established by the previous publisher, wanted to do things differently. In 1998, editors at Del Rey began plotting what became known as the New Jedi Order series: an ambitious multi-book, multi-author story that would reshape the galaxy far, far away. Hidalgo (2012) writes that while the series was initially envisioned as twenty-nine books, the series was shortened to nineteen books released between 1999 and 2003.

Because of the sheer scope of the project, Del Rey and Lucasfilm initiated a development committee to discuss the storyline, plot major points in the series, and ensure all parties were on the same page. This committee included editors from Del Rey, representatives from Lucasfilm, and authors James Luceno, Kathy Tyers, and Michael Stackpole (Star Wars, 2000). In an interview from 2000, Stackpole described the process: "The discussions were wideranging, starting with the universe as a whole and the characters we wanted to have involved; how the series and characters would evolve and then details like aspects of Yuuzhan Vong society" (Star Wars, 2000).
The scope of Del Rey's ambitions necessitated creating a centralized source of information and knowledge about the storyline and ensuring that major beats were plotted out ahead of time in order to guide writers. Bringing the stakeholders together to create an outline to manage the series was a shift in how Lucasfilm and its publisher managed their resources, which could be seen as an attempt to prevent the type of duplication seen in the Bantam publishing era.

This shift in how information was organized and managed was not solely confined to the publishing arm of the company. In 2000, Lucasfilm decided that they needed to change how they handled the expanding amount of content being generated. The first prequel movie had premiered the year before, and the second one was already under development. There was no centralized database at this time documenting the various stories already published as novels, comics, or short stories. With the advent of the prequel trilogy and Lucas finally opening up that era to publishers, the database became even more vital. The increase in information about the Star Wars universe being generated necessitated a change in how that information was managed on an internal level. P rior to 2000, everything related to Star Wars was housed in various story binders kept by Lucasfilm for reference (Chee, 2012). Leland Chee was brought in to help design a system to not only catalogue what had come before, but also assist Lucasfilm in tracking what was in development (Chee, 2012).

The database, also known as the Holocron, became the main information repository for all things related to Star Wars, including pronunciations, costumes, and places where continuity did not quite align across different 
mediums (Chee, 2012). Chee, in his role as "Keeper of the Holocron," viewed everything being produced by Lucasfilm to help keep continuity as orderly as possible (Baker, 2008). He would also allow authors to use it if they needed information about past and future stories in order to write their novels. In an interview with a popular fan site, author Matthew Stover revealed that to write his novel set during the Clone Wars, Lucasfilm granted him access to the database for research purposes (TheForce.Net, n.d.). In an era before fandom wikis on the Internet began documenting and classifying the Star Wars universe for everyone's consumption, the Holocron was one of the only centralized depositories of information available for writers to consult.

However, the creation of the Holocron did not mean some of the problems with managing a growing franchise disappeared. The New Jedi Order outline underwent multiple revisions due to negative reception of The Phantom Menace and concern by George Lucas that audiences would confuse Anakin Skywalker and his grandson, Anakin Solo (Larsen, 2012). Changes in the timeline brought about by the establishment of new $\mathrm{G}$-level canon through the prequel movies and later TV show led to authors having to find creative ways to address those discrepancies in tie-in fiction. The internal timeline established by Zahn in Heir to the Empire became muddled with the addition of new content, underscoring that the C-level canon was not considered when developing new movies or TV shows (Zahn, 2011). Although Zahn (2011) jokes that issue away with an in-universe reference to sloppy record keeping and information being lost or destroyed, it became a reoccurring issue for fans who wanted a strict timeline of events. The timeline and continuity that had been one of the hallmarks of the EU was slowly becoming a tangled knot for fans trying to unravel it. Unfortunately, on the management side, as long as there was new $\mathrm{G}$-level content being created, there was little they could do to address those concerns about messiness within the canon.

On October 30, 2012, news broke that Disney was acquiring Lucasfilm with an eye to creating a trilogy set after Return of the J edi. This put the EU in a state of limbo. Although fans appreciated the EU's depth and the richness of the stories told, the sheer weight of the continuity and contradictions with source material was taking a toll. While some fans hoped that Disney would bring some of the well-loved novels like the Thrawn Trilogy to the movie screen, many thought otherwise. With Disney paying four billion dollars for the company, it seemed only logical that they would strike their own path and tell their own stories rather than stay with what had been told before (BBC, 2012). Some hoped that Star Wars would be set up as a multi-verse with the EU as an alternate timeline, similar to what the Star Trek franchise did with their most recent movies, so that the movies and TV shows told different stories. In less than two years, fans got their answer.

A blog post accompanied by a video appeared on April 25, 2014, announcing the fate of the EU. Lucasfilm stated that all the EU content published up until that point would be re-classified as "Legends" and that the tie-in fiction and comic lines would be rebooted. Everything released afterwards, in addition to the existing $\mathrm{G}$-level canon of the movies and TV show, would be part of a larger, unified canon overseen by the Lucasfilm Story Group (Star Wars, 2014). The Story Group, which included Chee, Hidalgo, and producer Kiri Hart, had been 
created by the new head of Lucasfilm back in 2012 to assist in the development of new movies and oversee the franchise's canon (Baker-W hitelaw, 2016). While the newly classified Legends novels and comics would remain in print and potentially be drawn upon as resources for the new status quo, their events would no longer be seen as having occurred. The hope was to eliminate the two camps developing the story that Hidalgo identified. Instead of George Lucas serving as the sole authority over what was considered part of the definitive version of Star Wars, there would be a group of individuals evaluating and discussing what would be included. Now every piece of Star Wars material would be monitored by one group of people whose job it is to serve as a centralized source of information and knowledge about the franchise and manage both the content and the ideas. With a designated authority over what Star Wars was, what it could be, and what it wasn't, how information was managed across the franchise changed.

At the Star Wars Celebration panel focusing on the Story Group, the senior fiction editor at Lucasfilm, J en Heddle, spoke about how the new publishing model functioned. As the liaison between Lucasfilm and Del Rey, she had previously served as the representative from the company in working with the editors and authors. After the reboot of the EU, her role changed. Working with the Story Group, they focused on both the smaller details, as well as a longer-term strategy across various publishers (Larsen, 2015). Events in an adult novel under development might be impacted by a comic book storyline currently being published, which might then impact a young adult novel currently under consideration (Larsen, 2015). The Story Group, in Heddle's words, served as her "brain trust" in coordinating all the various projects across different lines (Larsen, 2015). The structure of the Story Group allowed for both a micro and macro collaboration within the publishing line and encouraged a conversation between creators about different content.

In an interview earlier this year about his novel Catalyst, which serves as a prequel to the film Rogue One, author J ames Luceno described how the book was developed:

The book and the film were coming together in parallel because the book is very character-driven and so are great parts of the film. I was brought in fairly early, going back to 2015. I read the treatment, and then read the shooting script and had a couple of meetings with the Story Group to discuss various ways to go about writing this prequel. I was shown art and then got to see some early footage that informed some of the book. (Floyd, 2016, para. 3)

For Luceno, having the Story Group serve as a resource for both potential story ideas, as well as knowledge about the plan for Rogue One, was essential in crafting his novel. The Story Group was not only able to provide Luceno with information about the still inproduction film, but it was also able to provide insight into the characters and their motivations, which may not have been available information for previous authors.

While Star Wars had been previously managing information amongst the publishing line through its use of the Holocron and maintaining a supervisory position on what was being produced, the establishment of the Story Group can be seen as branching into the knowledge management sphere. Rather than focusing 
on the details of the story (the names of ships or alien species, the various timelines, or the lists of characters alive at a certain point in time), the Story Group is in charge of a larger, overarching vision for Star Wars. Their job is to help translate how different authors view characters across an entire franchise and coordinate the various projects on a much larger scale. This group of people ensures that each creator is envisioning Star W ars as a whole instead of prioritizing specific aspects of the narrative. Distributing knowledge of the franchise throughout a group of people prevents resources from being consolidated and monopolized in the mind of one individual to the limitation of others. If one person leaves, there are others within who prevent knowledge loss from affecting the line. In addition to that, they can take a longer view of the franchise and use that to help creators formulate the best stories possible. Their unique position gives them the opportunity to create an atmosphere where collaboration and communication across different segments of the company is encouraged, and break down the silos that may have developed under the previous system.

\section{Conclusion}

The Star Wars tie-in novels and their relationship with their parent company, while they initially developed along similar lines to other tie-in novels, evolved into something unique. $P$ art of that is due to the restructuring of Lucasfilm, but it can also be explained by Lucasfilm recognizing the need for information and knowledge management. Without information management at the beginning of the $E U$, the novels and comics could have easily spiralled into two very different timelines that might confuse and alienate readers. Information management in the form of the Holocron became a foundation of the EU, and now it has been augmented with knowledge management through the Story Group. Although it is too early to evaluate how effective this strategy will be once there are more movies, novels, and comics to juggle on a timeline, for the moment it appears to be working well. It is currently unknown if other franchises could implement a similar knowledge management plan without a change in how they value the canonocity of their tie-in materials. Other franchises would need to evaluate if jettisoning possibly decades' worth of continuity for the chance to realign canon across all mediums would add value to their product or anger their fan base. Even establishing an internal database for information management purposes, similar to the Holocron, may be too much effort for those lacking resources or commitment from their parent organization. Lucasfilm will be unique among franchises for how it manages its canon and continuity through its information and knowledge management systems, and only time will tell how effective it is.

\section{References}

Anders, C.J . (2008, September 23). What did Diane Duane think of Star Trek: Nemesis? R etrieved from http://io9.gizmodo.com/5053820/wha t-did-diane-duane-think-of-star-treknemesis

Anders, C.J . (2009, November 23). Untold adventures: The complete history of tie-in novels. Retrieved from http://io9.gizmodo.com/5411331/unt old-adventures-the-complete-historyof-tie-in-novels

Baker, C. (2008, August 18). Meet Leland Chee, the Star Wars franchise 
continuity cop. Retrieved from https://www.wired.com/2008/08/ffstarwarscanon/? currentPage $=$ all

Baker-W hitelaw, G. (2016, J uly 21). How the Lucasfilm Story Group controls every corner of the 'Star Wars' franchise. Retrieved from http://www.dailydot.com/parsec/starwars-celebration-lucasfilm-storygroup/

BBC. (2012, October 31). Disney buys Star Wars maker Lucasfilm from George Lucas. Retrieved from http://www.bbc.com/news/business20146942

Chee, L. (2006, December 21). What'd I say again? Select posts by me regarding continuity. Retrieved from http://web.archive.org/web/2007031 9051650/http://blogs.starwars.com/h olocron/33

Chee, L. (2012, J uly 20). What is the Holocron? Retrieved from http://www.starwars.com/news/whatis-the-holocron

Hidalgo, P. (2012). Star Wars: The essential reader's companion. New York, NY: Del Rey.

Floyd, J . (2016, November 15). Crafting Catalyst: J ames Luceno discusses his Rogue One prequel novel. Retrieved from http://www.starwars.com/news/crafti ng-catalyst-james-luceno-discusseshis-rogue-one-prequel-novelinterview
Kogge, M. (2015a). Of rebel dreams and dark empires: The making of a Star Wars legend. Star Wars Insider, (157), 44-51.

Kogge, M. (2015b). Death to the Dark Side! The making of Dark E mpire - Part III. Star Wars Insider, (159), 38-43.

Larsen, B. (2012, May 31). Origins day one recap: writing advice, Mara's death, and a whole bunch of EU goodness. Retrieved from http://toschestation.net/origins-day-one-recapmaras-death/

Larsen, B. (Producer). (2015, April 18). At Celebration: One Big Story Working Within the Star Wars Canon. Retrieved from http://toschestation.net/tosche-station-radio-atcelebration-one-big-story-workingwithin-the-star-wars-canon/

Miller, J.J . (n.d.). Star Trek: The Next Generation - Takedown. Retrieved from http://www.farawaypress.com/fiction/ books/startrektakedown.html

Star Wars (2000, J une 6). A galaxy in ruin an interview with Michael $A$. Stackpole. Retrieved from http://web.archive.org/web/2008060 2115233/http://www.starwars.com/e u/lit/novel/f20000606/index.html

Star Wars (2014, April 25). The legendary Star Wars Expanded Universe turns a new page. Retrieved from http://www.starwars.com/news/thelegendary-star-wars-expandeduniverse-turns-a-new-page 
TheF orce.Net (n.d.). Interview with Matthew Stover - Traitor author. R etrieved from http://theforce.net/jedicouncil/intervie w/mattstover.asp

Veekhoven, T. (2015, O ctober 30). West

End Games: Expanding a galaxy far, far away... R etrieved from

http://www.starwars.com/news/westend-games-expanding-that-galaxyfar-far-away
Zahn, T. (2011). Star Wars: Heir to the Empire $-20^{\text {th }}$ Anniversary Edition. New York, NY: Del Rey. 